\title{
Prostaglandin E Synthase
}

National Cancer Institute

\section{Source}

National Cancer Institute. Prostaglandin E Synthase. NCI Thesaurus. Code C112111.

Prostaglandin E synthase (152 aa, 17 kDa) is encoded by the human PT GES gene. This protein may play a role in TP53 induced apoptosis. 